\title{
Impact of Internal Factors on the Profitability of Banks: A Case of Commercial Banks in Bangladesh
}

\author{
Ayesha Siddiqua ${ }^{1}$, A. N. M. Minhajul Haque Chowdhury ${ }^{2 *}$ Abu Sayed Md. Mahmudul Haque \\ Chowdhury $^{3}$, Md. Mainuddin ${ }^{4}$, Md. Latifur Rahman ${ }^{5}$ \\ 1,2,5MBA Student, Department of Finance and Banking, Hajee Mohammad Danesh Science and Technology University, Dinajpur-5200, \\ BANGLADESH \\ ${ }^{3}$ Senior Lecturer, Department of English, University of Development Alternative, Dhaka-1209, BANGLADESH \\ ${ }^{4}$ MBA Student, Department of Marketing, Hajee Mohammad Danesh Science and Technology University, Dinajpur-5200, BANGLADESH \\ *E-mail for correspondence: mhchowdhury2016@gmail.com
}

https://doi.org/10.18034/abr.v7i1.5

\begin{abstract}
The internal factors of the bank have a great influence on the profitability of the banks. This study is an effort to disclose the effect of bank's internal factors on return on equity (ROE), return on asset (ROA), and net interest margin (NIM) of ten selected commercial banks in Bangladesh for the period of 2011-2015. Researchers used descriptive statistics, correlation and regression analysis as statistics tools to find out the results. The findings from descriptive statistics indicate that Eastern Bank Limited was ranked first regarding profitability. The correlation test found that total equity to total asset ratio (TETA) and cost to income ratio (CIR) significantly affects the ROA whereas loan to deposit ratio had significant positive effect on the NIM of the banks. The regression analysis revealed that the independent variables of the banks were significant enough to explain the variation of the dependent variables (ROA, ROE, and NIM) of the study.
\end{abstract}

JEL Classifications: G 21

Keywords: Commercial banks, internal factors, return on asset, return on equity, net interest margin

\section{INTRODUCTION}

The development of banking sector is an indispensable way for a flourishing economy of a country which is developing in nature. The elevation of banks and the progression of the national economy are positively related in Bangladesh. The profitability of commercial banks is a response to some internal factors within the banks and some external factors. In fact, the main dominators of banking performance are the bank-specific factors. In this study the internal factors such as operating expense to total asset ratio (OETA), total equity to total asset ratio, cost to income ratio, loan to deposit ratio (LD), and cash to asset ratio (CA) are the point of concentration that has effect on the profitability of the commercial banks in Bangladesh.

\section{Objective of the Study}

The key objective of the study was to determine the influence of various internal factors on the profitability of commercial banks in Bangladesh.

\section{LITERATURE REVIEW}

A number of experimental works have been done relating the influence of bank-specific variables on the profitability of banking sectors. Almazari (2014) compared between Saudi Arabian and Jordanian banking sectors on the basis of some internal factors such as total investment to total asset ratio, liquidity risk, net credit facilities to total asset ratio, net credit to total deposit ratio, cost to income ratio , total equity to total asset ratio and bank size. He analyzed the financial data for the year 2005-2011 of 161 observations using ratio analysis, Pearson's correlation, descriptive statistics and regression analysis. The study revealed that total equity to total asset ratio had significant positive relation with the return on asset in both banking sector. According to Rose and Hudgins (2005) return on equity capital, return on assets, net interest margin, net non-interest margin, net operating margin, earnings per share of stock were the most important profitability ratios used in modern banking. They added that ROA indicates 
the managerial efficiency and ROE is likely to measure rates of return for the shareholders of bank whereas NIM is used both as profitability and efficiency measures. Shah and Jan (2014) studied on the private banks in Pakistan. They collected secondary data of 10 private commercial banks of Pakistan from the financial statement of the banks. They considered ROA and interest income as dependent variables and bank size, asset management and operational efficiency as the independent variables of the study. Their results from regression and correlation analysis suggested that ROA and net interest income had positive relations with both bank size and asset management but negative relations with operational efficiency. Petria et al. (2015) conducted a study on EU 27 banking system to find on the determinants those have significant impact on the profitability of the banks. The determinants were segmented into bank specific or internal factors and industry-specific and macroeconomic or external factors. Bank size, credit risk, capital adequacy, management efficiency, business mix indicator and liquidity risk were used as internal factors whereas market concentration, economic growth and inflation considered as external factors throughout the study. The findings of their analysis concluded that credit and liquidity risk, management efficiency, diversification of business, market competition and economic growth had significant influence on return on average asset and return on average equity. Ramlan and Adnan (2016) investigated the conventional and Islamic banks in Malaysia to find out the effect of independent variables (total equity to total asset, total loans to total asset and deposit to total asset) on the profitability of the banks which were measured by ROA and ROE. They used T-test model, regression and correlation as statistical tools for the analysis. The results showed that total equity to total asset was significantly related with ROA and ROE for both conventional and Islamic banks. Ayadi and Ellouze (2015) empirically analyzed the determinants of performance of the banks in Tunisia. They considered ROA as the performance indicator and selected quality of asset, capitalization, net interest income, non-interest income, bank size, inflation, ownership structure and revolution as the independent variables. They used different descriptive statistics, correlation matrix, variance inflation factor, homogeneity test, Fisher statistics, Housman test, autocorrelation test, test of normality of residuals etc to find out the appropriate results of their study. They found that bank's performance was positively affected by capitalization, size of the bank, inflation and ownership structure. On the contrary asset quality, net interest income, non-interest income and revolution had a negative effect on the performance of Tunisian banks. Kedia (2016) investigated Indian public sector banks to find out the determinants of profitability of the banks. Multiple regression analysis was the basic tool of the study where net profit was the profitability indicating variable and net interest income, non-performing asset, credit-deposit ratio and operating expenses were independent variables. By analyzing these data it was found that net profit had significant positive relationship with net interest income, credit-deposit ratio and operating expenses. On the other hand there was a significant negative relationship between net profit and non-performing asset. Ongore and Kusa (2013) tried to find out the effect of bank-specific factors (capital adequacy, asset management, management efficiency and liquidity management) and macroeconomic variables (GDP growth rate and inflation rate) on the performance (ROA, ROE and NIM) of commercial banks in Kenya. They applied generalized least square model on panel data and linear multiple regression analysis to reach a calculation. By analyzing the financial data of the banks they concluded that bank-specific factors had significant influence whereas macroeconomic factors considered as insignificant determinants of financial performance of commercial banks in Kenya. Samad (2015) examined 42 commercial banks in Bangladesh for the year 2009 and 2010 to measure the profitability of the banks based on internal and macroeconomic determinants. The results of the research indicated that there was a significant effect of loan-deposit ratio, loan-loss provision to total asset ratio, equity capital to total asset ratio and operating expenses to total asset ratio on the profitability of commercial banks in Bangladesh. Azar et al. (2016) conducted a study on the 39 banks of Lebanon where they used return on average asset as the dependent variable. On the other hand the internal factors such as interest rate spread, capital adequacy ratio, cost to income ratio and non-interest income to total asset ratio were the determinants of profitability of the banks. Descriptive statistics and Panel Least Square method were the main statistical tools. The empirical study suggested that the internal factors were statistically highly significant to explain the variation of profitability indicating variable. Kumbirai and Webb (2010) analyzed the financial ratios to determine the performance trend of the banks in South Africa during 2005-2009. In their study ROA, ROE and cost to income ratio were used to measure profitability of the banks whereas liquid asset to deposit borrowing ratio, net loans to asset ratio and net loans to deposit and borrowing ratio were used to measure the liquidity performance. At the same time loan loss reserve to gross loans was the indicator of asset credit quality. The findings concluded that the profitability, liquidity and credit quality were decreasing in the banking sector of South Africa. Dawood (2014) investigated 23 commercial banks in Pakistan in order to identify the impact of internal factors on the profitability of the banks for the period of 2009-2012. In his study the internal factors were cost efficiency (cost to income ratio), liquidity (liquid asset to customer deposit and short-term borrowed funds), deposit to asset ratio and size of the banks whereas ROA was used to measure profitability of the banks. The empirical analysis resulted cost efficiency, liquidity and capital adequacy had effect on profitability but deposit and bank size were insignificant in measuring profitability 
of the selected commercial banks in Pakistan. Raharjo et al. (2014) studied on the commercial banks in Indonesia to analyze the effect of internal and external factors on net interest margin of the banks. The internal factors of the study were asset growth, return on asset, operating cost to operating income, capital adequacy ratio, statutory reserves, loan to deposit, market share of loan and nonperforming loans while inflation rate of the economy and guaranteed interest rate were the main external influential factors. The correlation results showed that asset growth, ROA, loan to deposit had positive impact but operating cost to operating income, capital adequacy ratio, reserve and non-performing loans had negative impact on NIM. Sehrish et al. (2012) compared the financial performance of Islamic and Conventional Banks in Pakistan on the basis of profitability ratios (return on asset, return on deposit). They also used cost to income ratio in measuring operational efficiency of some selected banks in Pakistan. Jahangir et al. (2007) conducted a study on 23 listed banks in Dhaka Stock Exchange (DSE) and collected data from the Annual Reports of the banks for the period of 20002005. They used return on equity as the profitability ratio. On the contrary market size (Individual bank deposit to total bank deposit ratio), market concentration index and bank's risk measure (total loan to total deposit ratio) were the independent variables of the study. They used correlation analysis and stepwise regression model to find out the results. The findings of the empirical study provided the evidence that market concentration and market size had significant positive correlation with ROE but bank size negatively influenced the profitability ratio of the study.

\section{Research Methodology and Design}

Authors used the financial statements of the selected commercial banks in Bangladesh to conduct the study appropriately. The sample size of the study included 10 private commercial banks of Bangladesh and the banks are stated below:

- AB Bank Limited

- Bank Asia Limited

- Dhaka Bank Limited

- Eastern Bank Limited

- IFIC Bank Limited

- Mercantile Bank Limited

- Mutual Trust Bank Limited

- NCC Bank Limited

- Premier Bank Limited

- Prime Bank Limited

Researchers collected data from annual reports of the selected banks for the period of 2011-2015. Also data from books and journals were used in this study. Different statistical tools like descriptive statistics (mean, median, standard deviation, minimum, maximum, skewness, and kurtosis), correlation and regression analysis had been used to analyze the data.
The formulas of financial ratios used in the study are given below:

\begin{tabular}{|l|l|c|}
\hline \multicolumn{1}{|c|}{ Ratios } & & Formulas \\
\hline $\begin{array}{l}\text { Operating Expense to } \\
\text { Total Asset Ratio }\end{array}$ & OETA & $\frac{\text { Total Operating Expenses }}{\text { Total Asset }}$ \\
\hline $\begin{array}{l}\text { Total Equity to Total } \\
\text { Asset Ratio }\end{array}$ & TETA & $\frac{\text { Total Equity }}{\text { Total Asset }}$ \\
\hline Cost to Income Ratio & CIR & $\frac{\text { Total Operating Expenses }}{\text { Total Operating Income }}$ \\
\hline Loan to deposit Ratio & LD & $\frac{\text { Total Loans \& Advances }}{\text { Total Deposit }}$ \\
\hline Cash to Asset Ratio & CA & $\frac{\text { Total Cash }}{\text { Total Asset }}$ \\
\hline Return on Asset & ROA & $\frac{\text { Profit after Tax }}{\text { Average Total Asset }}$ \\
\hline Return on Equity & ROE & $\frac{\text { Profit after Tax }}{\text { Average Total Equity }}$ \\
\hline Net Interest Margin & NIM & $\frac{\text { Net Interest Income }}{\text { Total Asset }}$ \\
\hline
\end{tabular}

Regression equations for three dependent variables have been categorized in 3 models which are:

\section{Model 1:}

$\mathrm{ROA}=\beta_{0}+\beta_{1}(\mathrm{OETA})+\beta_{2}($ TETA $)+\beta_{3}(\mathrm{CIR})+\beta_{4}(\mathrm{LD})+$ $\beta_{5}(\mathrm{CA})+\varepsilon_{\mathrm{it}}$

\section{Model 2:}

$\mathrm{ROE}=\beta_{0}+\beta_{1}(\mathrm{OETA})+\beta_{2}(\mathrm{TETA})+\beta_{3}(\mathrm{CIR})+\beta_{4}(\mathrm{LD})+$ $\beta_{5}(\mathrm{CA})+\varepsilon_{\mathrm{it}}$

Model 3:

$\mathrm{NIM}=\beta_{0}+\beta_{1}(\mathrm{OETA})+\beta_{2}(\mathrm{TETA})+\beta_{3}(\mathrm{CIR})+\beta_{4}(\mathrm{LD})+$ $\beta_{5}(\mathrm{CA})+\varepsilon_{\text {it }}$

Where,

$\beta_{0}:$ Represents the intercept.

$\beta_{1}, \beta_{2}, \beta_{3}, \beta_{4}, \beta_{5}$ : Represents the coefficients of regression relations.

$\varepsilon_{\mathrm{it}}:$ Represents error term

The hypothesis of the study:

The Hypothesis for model 1:

Null Hypothesis, $\mathrm{H}_{0}$ : There is no relationship among ROA, OETA, TETA, CIR, LD, CA, and OETA.

An alternative hypothesis, $\mathrm{H}_{1}$ : There is a relationship among ROA, OETA, TETA, CIR, LD, CA, and OETA.

The Hypothesis for model 2:

Null Hypothesis, $\mathrm{H}_{0}$ : There is no relationship among ROE, OETA, TETA, CIR, LD, CA, and OETA.

An alternative hypothesis, $\mathrm{H}_{1}$ : There is a relationship among ROE, OETA, TETA, CIR, LD, CA, and OETA. 


\section{The Hypothesis for model 3:}

Null Hypothesis, $\mathrm{H}_{0}$ : There is no relationship among NIM, OETA, TETA, CIR, LD, CA, and OETA.

An alternative hypothesis, $\mathrm{H}_{1}$ : There is a relationship among NIM, OETA, TETA, CIR, LD, CA, and OETA.

\section{Results AND ANALYsis}

Table 1 shows the descriptive statistics of internal and profitability variables of each bank whereas Table 2 is the summary of descriptive statistics of all the selected banks. Table 1 and Table 2 have shown the evidence that OETA was the highest of Premier Bank Limited but the lowest of Dhaka Bank Limited while the highest variation in the result (SD) came in IFIC Bank Limited. Total equity to total asset which is the indicator of asset quality was the highest of Eastern Bank Limited whereas Mutual Trust Bank Limited was ranked the lowest regarding asset quality. Premier Bank Limited incurred a total cost in proportion to total income among all the selected conventional banks. LD ratio was highest of Eastern Bank Limited which was 1.02. On the other hand, Mutual Trust Bank Limited had lowest LD ratio during the period. Dhaka Bank Limited had the maximum cash to asset ratio (CA), but Bank Asia had minimum CA ratio. ROA and NIM were highest of Eastern Bank Limited, but lowest of Mutual Trust Bank Limited whereas Mercantile Bank Limited was the topper regarding return on equity (ROE).

Table 1: Descriptive statistics of each bank

\begin{tabular}{|c|c|c|c|c|c|c|c|c|c|}
\hline & OETA & TETA & CIR & LD & CA & ROA & ROE & NIM \\
\hline \multicolumn{8}{|c|}{ AB Bank Limited } \\
\hline Mean & .022 & .087 & .459 & .912 & .057 & .007 & .081 & .021 \\
\hline SD & .002 & .008 & .038 & .073 & .003 & .002 & .014 & .004 \\
\hline Min & .020 & .080 & .423 & .812 & .054 & .005 & .066 & .016 \\
\hline Max & .025 & .097 & .515 & 1.01 & .061 & .010 & .095 & .026 \\
\hline \multicolumn{8}{|c|}{ Bank Asia Limited } \\
\hline Mean & .021 & .092 & .393 & .840 & .056 & .012 & .129 & .020 \\
\hline SD & .001 & .009 & .026 & .028 & .006 & .005 & .054 & .006 \\
\hline Min & .020 & .083 & .365 & .807 & .047 & .007 & .066 & .012 \\
\hline Max & .022 & .107 & .427 & .876 & .060 & .018 & .208 & .026 \\
\hline \multicolumn{8}{|c|}{ Dhaka Bank Limited } \\
\hline Mean & .018 & .081 & .402 & .857 & .092 & .013 & .166 & .019 \\
\hline SD & .001 & .006 & .061 & .023 & .010 & .006 & .077 & .005 \\
\hline Min & .016 & .073 & .306 & .830 & .082 & .007 & .083 & .011 \\
\hline Max & .020 & .089 & .468 & .891 & .104 & .023 & .283 & .023 \\
\hline \multicolumn{8}{|c|}{ Eastern Bank Limited } \\
\hline Mean & .024 & .117 & .406 & 1.02 & .059 & .017 & .141 & .027 \\
\hline SD & .002 & .006 & .054 & .079 & .009 & .005 & .033 & .006 \\
\hline Min & .023 & .108 & .345 & .883 & .051 & .013 & .110 & .019 \\
\hline Max & .026 & .124 & .483 & 1.08 & .073 & .026 & .190 & .033 \\
\hline \multicolumn{8}{|c|}{ IFIC Bank Limited } \\
\hline Mean & .029 & .070 & .552 & .837 & .072 & .010 & .133 & .022 \\
\hline SD & .003 & .006 & .030 & .046 & .007 & .004 & .060 & .002 \\
\hline Min & .025 & .061 & .504 & .777 & .065 & .004 & .061 & .019 \\
\hline Max & .032 & .075 & .585 & .896 & .084 & .014 & .194 & .025 \\
\hline
\end{tabular}

\begin{tabular}{|c|c|c|c|c|c|c|c|c|}
\hline \multicolumn{10}{|c|}{ Mercantile Bank Limited } \\
\hline Mean & .021 & .082 & .454 & .834 & .072 & .014 & .173 & .014 \\
\hline SD & .002 & .006 & .035 & .034 & .007 & .003 & .027 & .002 \\
\hline Min & .019 & .072 & .420 & .791 & .060 & .010 & .132 & .011 \\
\hline Max & .023 & .087 & .508 & .868 & .079 & .017 & .208 & .015 \\
\hline \multicolumn{7}{|c|}{ Mutual Trust Bank Limited } \\
\hline Mean & .025 & .058 & .582 & .775 & .069 & .007 & .112 & .013 \\
\hline SD & .001 & .005 & .032 & .046 & .006 & .003 & .045 & .004 \\
\hline Min & .023 & .052 & .545 & .706 & .062 & .004 & .068 & .009 \\
\hline Max & .027 & .063 & .620 & .824 & .077 & .010 & .174 & .020 \\
\hline \multicolumn{8}{|c|}{ NCC Bank Limited } \\
\hline Mean & .019 & .105 & .318 & .906 & .063 & .014 & .132 & .020 \\
\hline SD & .002 & .005 & .169 & .040 & .001 & .006 & .055 & .002 \\
\hline Min & .017 & .096 & .035 & .852 & .061 & .010 & .092 & .018 \\
\hline Max & .021 & .109 & .445 & .960 & .063 & .025 & .228 & .024 \\
\hline \multicolumn{8}{|c|}{ Premier Bank Limited } \\
\hline Mean & .035 & .085 & .709 & .780 & .065 & .008 & .097 & .020 \\
\hline SD & .008 & .005 & .084 & .052 & .003 & .001 & .014 & .003 \\
\hline Min & .027 & .078 & .640 & .708 & .060 & .007 & .079 & .017 \\
\hline Max & .047 & .089 & .811 & .839 & .069 & .010 & .114 & .023 \\
\hline \multicolumn{8}{|c|}{ Prime Bank Limited } \\
\hline Mean & .023 & .096 & .430 & .825 & .069 & .016 & .121 & .016 \\
\hline SD & .001 & .006 & .074 & .069 & .002 & .009 & .049 & .008 \\
\hline Min & .022 & .088 & .348 & .746 & .067 & .008 & .085 & .005 \\
\hline Max & .025 & .105 & .517 & .907 & .072 & .030 & .202 & .024 \\
\hline
\end{tabular}

Table 2: Descriptive Analysis of all the Banks

\begin{tabular}{|c|c|c|c|c|c|c|c|c|}
\hline \multirow{2}{*}{ Variables } & \multirow{2}{*}{ Min } & \multirow{2}{*}{ Max } & \multirow{2}{*}{ Mean } & \multirow{2}{*}{ SD } & \multicolumn{2}{|c|}{ Skewness } & \multicolumn{2}{|c|}{ Kurtosis } \\
\cline { 6 - 9 } & & & & & Statistic & $\begin{array}{c}\text { Std. } \\
\text { Error }\end{array}$ & Statistic & $\begin{array}{c}\text { Std. } \\
\text { Error }\end{array}$ \\
\hline OETA & .018 & .035 & .024 & .005 & 1.33 & .687 & 1.83 & 1.33 \\
\hline TETA & .058 & .117 & .087 & .017 & .000 & .043 & 0.40 & 1.33 \\
\hline CIR & .318 & .709 & .470 & .114 & .013 & 1.02 & 0.96 & 1.33 \\
\hline LD & .775 & 1.02 & .858 & .072 & .005 & 1.23 & 1.98 & 1.33 \\
\hline CA & .056 & .092 & .067 & .011 & .000 & 1.47 & 3.06 & 1.33 \\
\hline ROA & .007 & .017 & .012 & .004 & .000 & -.02 & -1.49 & 1.33 \\
\hline ROE & .081 & .173 & .129 & .028 & .001 & -.11 & .09 & 1.33 \\
\hline NIM & .013 & .027 & .019 & .004 & .000 & .268 & .600 & 1.33 \\
\hline
\end{tabular}

The Pearson correlation matrix of all the variables is summarized in Table 3. The table shows that ROA and ROE had a positive correlation with TETA, LD, and CA but a negative correlation with OETA and CIR. There was a significant positive correlation between LD and NIM. CIR and CA negatively influenced NIM while OETA and TETA had a positive correlation with NIM. On the other hand, CA was negatively related to OETA and TETA, but there existed with a weak positive relationship between CA and CIR. There was a significant positive correlation between LD and TETA. Moreover, OETA had a negative relationship with TETA and LD. At the same time, CIR and OETA were significantly and positively correlated in this study. 
Table 3: Correlation Analysis

\begin{tabular}{|c|c|c|c|c|c|c|c|c|c|}
\hline & & OETA & TETA & CIR & LD & CA & ROA & ROE & NIM \\
\hline \multirow{2}{*}{ OETA } & Pearson Correlation & 1 & -.265 & $.907^{* *}$ & -.363 & -.181 & -.461 & -.478 & .104 \\
\cline { 2 - 10 } & Sig. (2-tailed) & & .459 & .000 & .302 & .616 & .180 & .162 & .774 \\
\hline \multirow{2}{*}{ TETA } & Pearson Correlation & -.265 & 1 & -.588 & $.773^{* *}$ & -.431 & $.724^{*}$ & .034 & .629 \\
\cline { 2 - 10 } & Sig. (2-tailed) & .459 & & .074 & .009 & .214 & .018 & .925 & .051 \\
\hline \multirow{2}{*}{ CIR } & Pearson Correlation & $.907^{* *}$ & -.588 & 1 & -.608 & .032 & $-.663^{*}$ & -.422 & -.217 \\
\cline { 2 - 10 } & Sig. (2-tailed) & .000 & .074 & & .062 & .930 & .037 & .225 & .547 \\
\hline \multirow{2}{*}{ LD } & Pearson Correlation & -.363 & $.773^{* *}$ & -.608 & 1 & -.318 & .527 & .104 & $.781^{* *}$ \\
\cline { 2 - 11 } & Sig. (2-tailed) & .302 & .009 & .062 & & .370 & .117 & .775 & .008 \\
\hline \multirow{2}{*}{ CA } & Pearson Correlation & -.181 & -.431 & .032 & -.318 & 1 & .112 & .591 & -.320 \\
\cline { 2 - 10 } & Sig. (2-tailed) & .616 & .214 & .930 & .370 & & .757 & .072 & .368 \\
\hline \multirow{2}{*}{ ROA } & Pearson Correlation & -.461 & $.724^{*}$ & $-.663^{*}$ & .527 & .112 & 1 & .610 & .237 \\
\cline { 2 - 11 } & Sig. (2-tailed) & .180 & .018 & .037 & .117 & .757 & & .061 & .509 \\
\hline \multirow{2}{*}{ ROE } & Pearson Correlation & -.478 & .034 & -.422 & .104 & .591 & .610 & 1 & -.149 \\
\cline { 2 - 10 } & Sig. (2-tailed) & .162 & .925 & .225 & .775 & .072 & .061 & & .682 \\
\hline \multirow{2}{*}{ NIM } & Pearson Correlation & .104 & .629 & -.217 & $.781^{* *}$ & -.320 & .237 & -.149 & 1 \\
\cline { 2 - 10 } & Sig. (2-tailed) & .774 & .051 & .547 & .008 & .368 & .509 & .682 & \\
\hline
\end{tabular}

**Correlation is significant at the 0.01 level (2-tailed).

*Correlation is significant at the 0.05 level (2-tailed).

The regression analysis was tested considering three dependent variables (ROA, ROE, and NIM) and Table 4 summarizes the results of the regression analysis. The R-square of model 1, model 2 and model 3 are $0.794,0.552$ and 0.835 respectively. This table indicates that the independent variables OETA, TETA, CIR, LD and CA could explain the changes in the dependent variables ROA by $79 \%$, ROE of $55 \%$ and NIM by $84 \%$. This also provided the evidence that the alternative hypotheses of the study were accepted.

Table 4: Regression Analysis

\begin{tabular}{|c|c|c|c|c|c|c|c|c|c|c|c|c|}
\hline \multirow{2}{*}{ Models } & \multirow{2}{*}{ Variables } & \multicolumn{2}{|c|}{$\begin{array}{l}\text { Unstandardized } \\
\text { Coefficients }\end{array}$} & \multirow{2}{*}{$\begin{array}{c}\begin{array}{c}\text { Standardized } \\
\text { Coefficients }\end{array} \\
\text { Beta } \\
\end{array}$} & \multirow{2}{*}{$\mathbf{t}$} & \multirow{2}{*}{ Sig. } & \multicolumn{2}{|c|}{$\begin{array}{c}\text { Collinearity } \\
\text { Statistics }\end{array}$} & \multicolumn{4}{|c|}{ Model Summary } \\
\hline & & B & $\begin{array}{l}\text { Std. } \\
\text { Error }\end{array}$ & & & & Tolerance & VIF & $\mathbf{R}$ & $\mathbf{R}^{2}$ & $\begin{array}{c}\text { Adjusted } \\
\mathbf{R}^{2} \\
\end{array}$ & $\begin{array}{c}\text { Std. Error } \\
\text { of estimate }\end{array}$ \\
\hline \multirow{6}{*}{$\begin{array}{l}\text { Model } 1 \\
\text { (Dependent } \\
\text { variable } \\
\text { ROA) }\end{array}$} & Constant & -.001 & .020 & & -.072 & .946 & & & \multirow{6}{*}{0.891} & \multirow{6}{*}{0.794} & \multirow{6}{*}{0.537} & \multirow{6}{*}{0.002} \\
\hline & OETA & .298 & .676 & .395 & .441 & .682 & .064 & 15.603 & & & & \\
\hline & TETA & .171 & .110 & .784 & 1.556 & .195 & .203 & 4.936 & & & & \\
\hline & CIR & -.023 & .034 & -.703 & -.659 & .546 & .045 & 22.154 & & & & \\
\hline & LD & -.011 & .019 & -.211 & -.559 & .606 & .360 & 2.774 & & & & \\
\hline & CA & .166 & .093 & .478 & 1.776 & .150 & .712 & 1.405 & & & & \\
\hline \multirow{6}{*}{$\begin{array}{l}\text { Model } 2 \\
\text { (Dependent } \\
\text { variable } \\
\text { ROE) }\end{array}$} & Constant & .061 & .229 & & .265 & .804 & & & \multirow{6}{*}{0.743} & \multirow{6}{*}{0.552} & \multirow{6}{*}{-0.009} & \multirow{6}{*}{0.028} \\
\hline & OETA & 1.613 & 7.564 & .282 & .213 & .842 & .064 & 15.603 & & & & \\
\hline & TETA & -.057 & 1.233 & $\begin{array}{l}.034 \\
\end{array}$ & $\begin{array}{l}.046 \\
\end{array}$ & .965 & .203 & 4.936 & & & & \\
\hline & CIR & -.175 & .386 & -.715 & -.454 & .673 & .045 & 22.154 & & & & \\
\hline & LD & .002 & .215 & .005 & .009 & .993 & .360 & 2.774 & & & & \\
\hline & CA & 1.719 & 1.046 & .652 & 1.644 & .176 & .712 & 1.405 & & & & \\
\hline \multirow{6}{*}{$\begin{array}{l}\text { Model } 3 \\
\text { (Dependent } \\
\text { variable } \\
\text { NIM) }\end{array}$} & Constant & -.030 & .021 & & -1.455 & .219 & & & \multirow{6}{*}{0.914} & \multirow{6}{*}{0.835} & \multirow{6}{*}{0.629} & \multirow{6}{*}{0.003} \\
\hline & OETA & 1.071 & .680 & 1.263 & 1.574 & .191 & .064 & 15.603 & & & & \\
\hline & TETA & -.053 & .111 & -.215 & -.477 & .658 & .203 & 4.936 & & & & \\
\hline & CIR & -.035 & .035 & -.975 & -1.020 & .365 & .045 & 22.154 & & & & \\
\hline & LD & .049 & .019 & .851 & 2.515 & .066 & .360 & 2.774 & & & & \\
\hline & $\mathrm{CA}$ & .046 & .094 & .119 & .493 & .648 & .712 & 1.405 & & & & \\
\hline
\end{tabular}

\section{CONCLUSION}

This study examined the effect of the internal factors or firm specific factors of some selected commercial bank on their profitability. The statistical tests revealed some issues such as total equity to total asset and loan to deposit had a positive effect on the determinants of profitability which are ROA, ROE, and NIM. The cost to income ratio put its negative effect on profitability. OETA and CA ratio did not have a uniform influence on the profitability. Cash out of asset positively affect ROA and ROE, but it influenced the NIM negatively. The findings also indicated that the internal factors confined to the banks were sufficient to explain the changes in the ROA, ROE, and NIM of the selected banks in Bangladesh.

\section{ACKNOWLEDGEMENT}

The authors wish to thank Md. Jahangir Alam Siddikee for his unconditional support and guidance to accomplish the research work. 


\section{REFERENCES}

Almazari A. A. (2014). "Impact of internal factors on bank profitability: comparative study between Saudi Arabia and Jordan," Journal of Applied Finance E Banking, vol. 4, no. 1, pp. $125-140$.

Ayadi I. \& Ellouze A. (2015). "The determinants of the Tunisian banking performance; A panel data analysis," International Journal of Economics and Finance, vol. 7, no. 1, pp. 262-272.

Azar S. A., Bolbol A. \& Mouradian A. (2016). "Profitability of banks in Lebanon: some theoretical and empirical results," International Journal of Economics and Finance, vol. 8, no. 7, pp. 233-243.

Chowdhury, A., Siddiqua, A., \& Chowdhury, A. (2016). Relationship between Liquidity Risk and Net Interest Margin of Conventional Banks in Bangladesh. Asian Business Review, 6(3), 175-178.

Dawood U. (2014). "Factors impacting the profitability of commercial banks in Pakistan for the period of (20092012)," International Journal of Scientific and Research Publications, vol. 4, no. 3, pp. 1-7.

Jahangir N., Shill S. \& Haque M. A. J. (2007). “Examination of Profitability in the Context of Bangladesh," ABAC Journal, vol. 27, no. 2, pp. 36-46.

Kedia N. (2016). "Determinants of profitability of Indian public sector banks," Ira- International Journal of Management $\mathcal{E}$ Social Sciences, vol. 2, no. 3, pp. 1-16.

Kumbirai M. \& Webb R. (2010). "A financial ratio analysis of commercial bank performance in South Africa," African Review of Economics and Finance, vol. 2, no. 10, pp. 30-53.

Ongore V. O. \& Kusa G. B. (2013). "Determinants of the financial performance of commercial banks in Kenya," International Journal of Economics and Financial Issues, vol. 3, no. 1, pp. 237-252.
Petria N., Capraru B. \& Ihnatov I. (2015). "Determinants of bank's profitability: Evidence from EU 27 banking systems," in 7th International Conference on Globalization and Higher Education in Economics and Business Administration, GEBA, 2013, Procedia Economics and Finance, pp. 518-524.

Raharjo P. G., Hakim D. B., Manurung A. H. \& Maulana T. N. A. (2014). "The determinants of commercial banks interest margin in Indonesia: An analysis of fixed effect panel regression," International Journal of Economics and Financial Issues, vol. 4, no. 2, pp. 295-308.

Ramlan H. \& Adnan M. S. (2016). "The profitability of Islamic and Conventional Banks: Case Study in Malaysia," in 7th International Economics \& Business Management Conference, 5th and 6th October 2015, Procedia Economics and Finance, pp. 359-367.

Rose P. S. \& Hudgins S. C. (2005). Bank Management \& Financial Services. Sixth edition, McGraw-Hill Education, pp. 145-192.

Samad A. (2015). "Determinants bank profitability: Empirical evidence from Bangladesh Commercial Banks," International Journal of Financial Research, vol. 6, no. 3, pp. 173-179.

Sehrish S., Saleem F., Yasir M., Shehzad F. \& Ahmed K. (2012). "Financial performance analysis of Islamic banks and Conventional banks in Pakistan," Interdisciplinary Journal of Contemporary Research in Business, vol. 4, no. 5, pp. 186-200.

Shah S. Q. \& Jan R. (2014). "Analysis of financial performance of private banks in Pakistan," in $2^{\text {nd }}$ World Conference on Business, Economics and Management-WCBEM, 2013, Procedia- Social and Behavioral Sciences, pp. 1021-1025.

$--0--$ 


\section{APPENDICES}

Appendix 1: Internal variables of each bank

\begin{tabular}{|c|c|c|c|c|c|c|c|c|c|c|c|}
\hline \multirow[b]{2}{*}{ Year } & \multirow[b]{2}{*}{ Ratios } & \multicolumn{10}{|c|}{ Name of the Banks } \\
\hline & & $\begin{array}{c}\text { AB } \\
\text { Bank }\end{array}$ & $\begin{array}{l}\text { Bank } \\
\text { Asia }\end{array}$ & $\begin{array}{l}\text { Dhaka } \\
\text { Bank }\end{array}$ & $\begin{array}{c}\text { Eastern } \\
\text { Bank }\end{array}$ & $\begin{array}{l}\text { IFIC } \\
\text { Bank }\end{array}$ & $\begin{array}{l}\text { Mercantile } \\
\text { Bank }\end{array}$ & $\begin{array}{c}\text { Mutual } \\
\text { Trust }\end{array}$ & $\begin{array}{l}\text { NCC } \\
\text { Bank }\end{array}$ & $\begin{array}{c}\text { Premier } \\
\text { Bank }\end{array}$ & $\begin{array}{l}\text { Prime } \\
\text { Bank }\end{array}$ \\
\hline \multirow{5}{*}{2011} & OETA & 0.02410 & 0.02206 & 0.01869 & 0.02322 & 0.03179 & 0.02261 & 0.02487 & 0.01701 & 0.04679 & 0.02172 \\
\hline & TETA & 0.09725 & 0.10670 & 0.08848 & 0.12412 & 0.07283 & 0.08342 & 0.06308 & 0.10913 & 0.08904 & 0.09605 \\
\hline & CIR & 0.42948 & 0.38158 & 0.30636 & 0.34522 & 0.50346 & 0.42746 & 0.61169 & 0.29032 & 0.81100 & 0.34837 \\
\hline & LD & 0.88469 & 0.87606 & 0.89102 & 1.07785 & 0.89576 & 0.84768 & 0.79602 & 0.90365 & 0.82011 & 0.88730 \\
\hline & $\mathrm{CA}$ & 0.06063 & 0.05948 & 0.09054 & 0.05123 & 0.07229 & 0.05957 & 0.06179 & 0.06188 & 0.06865 & 0.06715 \\
\hline \multirow{5}{*}{2012} & OETA & 0.02449 & 0.02035 & 0.01631 & 0.02250 & 0.03229 & 0.01874 & 0.02335 & 0.00178 & 0.03760 & 0.02167 \\
\hline & TETA & 0.09231 & 0.09285 & 0.07324 & 0.11731 & 0.06082 & 0.07190 & 0.05188 & 0.09633 & 0.08746 & 0.08801 \\
\hline & CIR & 0.47670 & 0.36459 & 0.38813 & 0.37517 & 0.56717 & 0.46100 & 0.62012 & 0.03535 & 0.78866 & 0.36867 \\
\hline & LD & 0.81241 & 0.84783 & 0.84506 & 1.05971 & 0.84999 & 0.79109 & 0.75208 & 0.85237 & 0.77858 & 0.90701 \\
\hline & CA & 0.05483 & 0.04670 & 0.08183 & 0.07343 & 0.08349 & 0.07865 & 0.07011 & 0.06133 & 0.06389 & 0.06797 \\
\hline \multirow{5}{*}{2013} & OETA & 0.02182 & 0.01948 & 0.01913 & 0.02374 & 0.02714 & 0.02164 & 0.02563 & 0.01967 & 0.03238 & 0.02317 \\
\hline & TETA & 0.08245 & 0.08819 & 0.08284 & 0.11734 & 0.07347 & 0.08706 & 0.05386 & 0.10657 & 0.08883 & 0.09514 \\
\hline & CIR & 0.45217 & 0.37752 & 0.41666 & 0.39183 & 0.54933 & 0.42037 & 0.56141 & 0.38460 & 0.65652 & 0.42389 \\
\hline & LD & 0.91040 & 0.80745 & 0.86535 & 0.88289 & 0.77723 & 0.80705 & 0.70578 & 0.92656 & 0.70763 & 0.78788 \\
\hline & CA & 0.05417 & 0.05883 & 0.10440 & 0.05172 & 0.07232 & 0.07169 & 0.07086 & 0.06319 & 0.06015 & 0.07195 \\
\hline \multirow{5}{*}{2014} & OETA & 0.02178 & 0.02199 & 0.01951 & 0.02569 & 0.02846 & 0.02169 & 0.02684 & 0.02109 & 0.03000 & 0.02335 \\
\hline & TETA & 0.08021 & 0.09018 & 0.08120 & 0.11667 & 0.07480 & 0.08020 & 0.05821 & 0.10557 & 0.08015 & 0.09589 \\
\hline & CIR & 0.42298 & 0.41225 & 0.42954 & 0.43194 & 0.58492 & 0.45402 & 0.54528 & 0.43287 & 0.64802 & 0.49013 \\
\hline & LD & 0.93247 & 0.85221 & 0.82981 & 1.02819 & 0.80407 & 0.86845 & 0.79440 & 0.88913 & 0.75569 & 0.74569 \\
\hline & CA & 0.05621 & 0.05949 & 0.09952 & 0.05940 & 0.06541 & 0.07625 & 0.07681 & 0.06333 & 0.06522 & 0.06850 \\
\hline \multirow{5}{*}{2015} & OETA & 0.01991 & 0.01992 & 0.01848 & 0.02621 & 0.02472 & 0.02222 & 0.02581 & 0.02124 & 0.02663 & 0.02512 \\
\hline & TETA & 0.08216 & 0.08285 & 0.07726 & 0.10836 & 0.06844 & 0.08471 & 0.06113 & 0.10625 & 0.07794 & 0.10456 \\
\hline & CIR & 0.51492 & 0.42730 & 0.46831 & 0.48330 & 0.55301 & 0.50768 & 0.57285 & 0.44527 & 0.63969 & 0.51710 \\
\hline & LD & 1.01260 & 0.81697 & 0.85275 & 1.05116 & 0.85577 & 0.85725 & 0.82420 & 0.95986 & 0.83875 & 0.79497 \\
\hline & $\mathrm{CA}$ & 0.05937 & 0.05526 & 0.08445 & 0.05727 & 0.06575 & 0.07197 & 0.06493 & 0.06285 & 0.06493 & 0.06911 \\
\hline
\end{tabular}

Appendix 2: Profitability indicators of each bank

\begin{tabular}{|c|c|c|c|c|c|c|c|c|c|c|c|}
\hline \multirow[b]{2}{*}{ Year } & \multirow[b]{2}{*}{ Ratios } & \multicolumn{10}{|c|}{ Name of the Banks } \\
\hline & & $\begin{array}{c}\text { AB } \\
\text { Bank }\end{array}$ & $\begin{array}{l}\text { Bank } \\
\text { Asia }\end{array}$ & $\begin{array}{c}\text { Dhaka } \\
\text { Bank }\end{array}$ & $\begin{array}{c}\text { Eastern } \\
\text { Bank }\end{array}$ & $\begin{array}{l}\text { IFIC } \\
\text { Bank }\end{array}$ & $\begin{array}{l}\text { Mercantile } \\
\text { Bank. }\end{array}$ & $\begin{array}{c}\text { Mutual } \\
\text { Trust }\end{array}$ & $\begin{array}{l}\text { NCC } \\
\text { Bank }\end{array}$ & $\begin{array}{c}\text { Premier } \\
\text { Bank }\end{array}$ & $\begin{array}{c}\text { Prime } \\
\text { Bank }\end{array}$ \\
\hline \multirow{3}{*}{2011} & ROA & 0.00965 & 0.01830 & 0.02298 & 0.02551 & 0.01028 & 0.01723 & 0.00604 & 0.02519 & 0.00714 & 0.02087 \\
\hline & ROE & 0.09535 & 0.20780 & 0.28256 & 0.19013 & 0.13361 & 0.20757 & 0.08793 & 0.22821 & 0.07890 & 0.20217 \\
\hline & NIM & 0.02152 & 0.02392 & 0.02287 & 0.02867 & 0.02335 & 0.01490 & 0.01163 & 0.02428 & 0.02319 & 0.02254 \\
\hline \multirow{3}{*}{2012} & $\mathrm{ROA}$ & 0.00886 & 0.00655 & 0.00661 & 0.01809 & 0.00404 & 0.01017 & 0.00387 & 0.01254 & 0.00770 & 0.01230 \\
\hline & ROE & 0.09365 & 0.06609 & 0.08267 & 0.15029 & 0.06100 & 0.13226 & 0.06796 & 0.12280 & 0.08731 & 0.13412 \\
\hline & NIM & 0.02171 & 0.02624 & 0.02073 & 0.03322 & 0.02493 & 0.01285 & 0.00913 & 0.01927 & 0.02134 & 0.02444 \\
\hline \multirow{3}{*}{2013} & ROA & 0.00570 & 0.00869 & 0.01420 & 0.01661 & 0.01310 & 0.01328 & 0.00590 & 0.01076 & 0.00916 & 0.00843 \\
\hline & ROE & 0.06559 & 0.09617 & 0.18153 & 0.14159 & 0.19368 & 0.16750 & 0.11150 & 0.10608 & 0.10383 & 0.09198 \\
\hline & NIM & 0.01947 & 0.01844 & 0.02308 & 0.03134 & 0.01941 & 0.01116 & 0.01016 & 0.01805 & 0.01756 & 0.01767 \\
\hline \multirow{3}{*}{2014} & ROA & 0.00656 & 0.01153 & 0.01375 & 0.01289 & 0.01406 & 0.01452 & 0.00884 & 0.01184 & 0.00954 & 0.00895 \\
\hline & ROE & 0.08073 & 0.12918 & 0.16777 & 0.11022 & 0.18956 & 0.17423 & 0.15738 & 0.11167 & 0.11359 & 0.09368 \\
\hline & NIM & 0.02603 & 0.01741 & 0.01792 & 0.02357 & 0.02141 & 0.01522 & 0.01578 & 0.01958 & 0.01731 & 0.01107 \\
\hline \multirow{3}{*}{2015} & ROA & 0.00545 & 0.01245 & 0.00898 & 0.01252 & 0.00622 & 0.01508 & 0.01041 & 0.00977 & 0.00791 & 0.03035 \\
\hline & ROE & 0.06703 & 0.14449 & 0.11346 & 0.11150 & 0.08712 & 0.18274 & 0.17404 & 0.09223 & 0.10022 & 0.08507 \\
\hline & NIM & 0.01610 & 0.01218 & 0.01141 & 0.01927 & 0.02088 & 0.01372 & 0.01961 & 0.02073 & 0.01786 & 0.00502 \\
\hline
\end{tabular}


Online Archive: https://abc.us.org/ojs/index.php/abr/issue/archive

\section{5) Worldcat Google scholar $a b c G A T E$ PBSE}

